\title{
TG pyrolysis of a mixture of dried sludge from urban wastewater and wood pellets and identification of the composition of the resulting gases by infrared spectroscopy
}

\author{
Giedrius Stravinskas, \\ Anupras Šlančiauskas \\ Lithuanian Energy Institute, \\ Laboratory of Combustion Processes, \\ Breslaujos St. 3, \\ 44403 Kaunas, Lithuania \\ Email: anupras.profesorius@gmail.com
}

\begin{abstract}
The recent tendency of sewage sludge disposal is targeted towards the gasification for heat generation in small towns far from waste incineration plants. The scope of this article is to present the investigation into the mixture of dried sewage sludge and wood pellets during pyrolysis by thermogravimetry (TG) with evolved gas analysis by TG-coupled Fourier transformation infrared spectroscopy (FTIR) method. The maximum intensity of mass loss of sewage sludge material occurs at $300-310^{\circ} \mathrm{C}$ temperature and it differs from wood cellulose case of $360^{\circ} \mathrm{C}$. The $50: 50 \%$ mixture of these materials was investigated in more details. Pyrolysis reaction kinetics is described by a variation of three constituent parts from TG data. Prefactor $A$ and activation energy $E$ of the Arrhenius law were found, and reaction order $n$ was determined by the Ozawa method employing Avrami phase change. The maximum of gas evolution is always related to the most intense mass loss, and gas composition correlates with the initial material
\end{abstract}

Keywords: pyrolysis; sewage sludge; TG-FTIR analysis

\section{INTRODUCTION}

With the growing requirements for food processing ecology, sewage sludge treatment by composting has become unwanted since this method has some drawbacks, such as lengthy period, sorting costs, site preparation, etc. Lithuania is a land with many small rivers and lakes, and conservation of clean water basin is an important issue. The target of sewage sludge treatment was shifted towards anaerobic digestion and storage for later treatment by gasification. The advantage of this method is lower storage space; however, utilisation requires some preparation process associated with certain risks, such as odour, dust fire, etc. Small and powdery grains of the digested waste are not suitable for direct usage in waste treatment plants because they accept briquette material.

The possible way to utilise sewage sludge in gasification facilities is simply to prepare blends of sewage sludge and wood, as digested sewage sludge contains considerable amount of non-combustible material. This was the reason for the investigation into sewage sludge and spruce wood pyrolysis presented in this article. Moreover, 
sewage sludge utilisation by gasification becomes the state-of-art technology both for environmentally-friendly waste disposal and energy production. The pyrolysis of sewage sludge was already investigated some decades ago $[1,2]$, and within this study, a comparison with softwood material is presented. The technique of gasification and pyrolysis of wood materials is described in detail [3]. Softwood properties and pyrolysis behaviour are also well known and the process of thermal decomposition of organic compounds has already been investigated in detail by many researchers. Wood structure - hemicellulose, cellulose, and lignin - enables wood pyrolysis to be treated as an entity of separate parallel decomposition reactions and to describe reaction kinetics in detail by the Arrhenius law and reaction order. In this analysis, spruce wood and sewage sludge were used to compare the data acquired with the data from other researchers, and pyrolysis behaviour of the mixture of these material is presented.

There are numerous comprehensive works on wood pyrolysis. The Norway spruce pyrolysis process was investigated in detail at low temperatures, i.e., at the zone of torrefaction technology, with main focus on the groups of released organic materials, such as acids, gluconates, etc. in [4]. The description of the pyrolysis reaction rate by the Arrhenius law was specified by ensuring the fact that reaction order is close to value 1 for biomass [5]. Some authors [6] conducted research on the process of pyrolysis of wood constituents and measured composition of the evolved gases. Some researches provided more detailed descriptions of the base of the rate of pyrolysis reaction, dependent on the initial composition of the raw material by chemical groups $[1,7,8]$. At the Laboratory of Combustion Processes of the Lithuanian Energy Institute, current wood gasification experiments are being carried out in down draft reactor [9] with different kinds of pelletized fuel. Coherently, micro-scale experiments are performed by thermogravimetric analysis. Heat exchange experiments are performed with pyrolysis of spruce pellet fuel and composition of the evolved gases is measured. The results match the results reported by other authors.

Due to stricter environmental regulations, in recent years special attention has been paid to py- rolysis research and analysis of different organic waste materials. Several directions of research deserve mention: data selection and generalisation for technological projects with respect to the different types of fuel and waste, methodology and theoretical evaluation, research on the rearrangement of chemical compounds.

In [10], TG analysis of 6-8 $\mathrm{mg}$ sewage sludge samples collected from both large (population 1.5 million) and small $(150,000)$ cities at heating rate of $10^{\circ} \mathrm{C} / \mathrm{min}$ under inert atmosphere was performed. From the data collected, it was found that $E$ values ranged from 138 up to 205 for sewage sludge samples from large cities, and $E$ from 120 up to 301 for samples from smaller city. The difference may be explained by a greater quantity of municipal waste in big cities. From the present situation with waste disposal, it can be stated that priority is for digested sewage sludge. Comparison of the properties of digested and non-digested sewage sludge shows the following principal differences [7]: digested sewage sludge contains more compounds with decomposition temperature within $250-350^{\circ} \mathrm{C}$ range, where yeast products from nutrients, such as yeast mycelium shells, amino acids, etc., predominate simultaneously with common hemicellulose. In the case of non-digested sewage sludge, the compounds with the same range of decomposition temperature are related to organic compounds, such as glucose, lactose, sugars, etc. Like in the comparison with wood, the cellulose content is lower and pyrolysis process at the temperature range $350-390^{\circ} \mathrm{C}$ is less intense in both cases of sewage sludge. Conesa et al. [7] performed thermal analysis of anaerobically digested and non-digested sewage sludge from the same source of origin and showed different decomposition behaviour already starting from the $200^{\circ} \mathrm{C}$ temperature. The mass loss of non-digested sewage sludge starts earlier and the character of the mass loss curve is consistent throughout the whole process. Digested sewage sludge loses mass more vigorously when approaching $300^{\circ} \mathrm{C}$ temperature.

Series of researches were performed on sewage sludge utilisation by blending with other fuels: with oil shale [11] and with coal [12]. The purpose of these researches was to develop an efficient way of utilising sewage sludge for 
energy production. Addition of $10 \%$ sewage sludge increased the efficiency of oil shale containing hydrocarbons combustion by $20 \%$ [11]. The analysis of pyrolysis of coal blends with sewage sludge [12] was performed, with most attention focused on the reduction of hazardous gases generated, such as $\mathrm{SO}_{2}$ and $\mathrm{CO}_{2}$.

A deeper insight is necessary into physical significances of the characteristic temperature zones and pyrolytic properties of the materials. Differences can be found by specifying the temperature and residual mass zones with relatively constant $A$ and $E$ values. Most of TG measurement results are described by distinguishing three parts in the pyrolysis reaction: amorphous hemicellulose compounds pyrolysis at temperatures up to $320^{\circ} \mathrm{C}$, cellulose specific temperatures up to $380^{\circ} \mathrm{C}$, and plenty of carbon bond containing materials, such as lignin, up to $500^{\circ} \mathrm{C}$. For a better description, a reaction order is used. A simple case of this type of analysis is the process of wood pyrolysis where characteristic zones of the mass loss of hemicellulose, cellulose, and lignin are described independently [14]. This type of methodology has been used for various waste materials by a number of authors. In [7], an interesting solution for the equation system with 22 variables is proposed, with the purpose of least square deviation from TG curve to find pyrolysis reaction constituents. Otero et al. [15] describe the well-known standard methodology [14] for finding $A$ and $E$ constants and summarise results by finding the reaction order for the formula of non-isothermal case developed by Ozawa [15] and Lambriger [16] according to the investigation into the Avrami phase change [17]. Organic compounds are composition of large and complex molecules and intermediate product of decomposition are also very complex; however, TG analysis with Arrhenius law method allows distinguishing and separating different groups with specific reaction rate. The standard of finding the $A$ and $E$ constants was proposed by [18] and [19].

The main aim of this article is to present investigations into the process of pyrolysis of sewage sludge and mixture of sewage sludge with spruce wood. Separate analysis of the pyrolysis process of both constituents - spruce wood and dried sewage sludge, with equal mass proportions, was seen as primary. The thermogravimetric (TG) analysis technique with evolved gas detection by Fourier transform infrared measurement was used. An iso-conversional method was applied to determine the kinetic parameters using multiple heating rates for thermogravimetric analysis and it was as a base for description of reaction kinetics. Additionally, the gasification process was illustrated and compared by plotting FTIR temperature profiles of the evolved gases during decomposition of the samples. The purpose was to analyse pyrolysis of fuel blends and to develop proper reaction conditions for carbon utilisation in the automatized gasification reactor.

\section{MATERIALS AND METHODS}

\section{Samples}

For thermogravimetric analysis with evolved gas analysis, the following samples were used: dried softwood (the Norway spruce), dried sewage sludge, 50:50 wt.\% mixture of dried sewage sludge with softwood.

Dried sewage sludge was collected from Šilutè (Lithuania) municipal sewage sludge treatment facilities after digestion and drying processes, prepared for further use in pilot scale gasification plant. The town of Šilute has just above 20,000 residents and is ranked the 18th town in Lithuania by population.

For the TG-EGA experiments, the materials were milled and fine-ground to obtain a homogeneous sample. The powder was sieved to obtain fraction smaller than $0.25 \mathrm{~mm}$. Weight of the samples was $6.5 \pm 0.1 \mathrm{mg}$.

Proximate and ultimate analysis of the samples was performed by IKA C5000 calorimeter and Flash 2000 CHNS analyser. Characteristics of the samples are presented in Table 1.

\section{Thermal analysis}

Thermal analysis of Norway spruce wood, sewage sludge, and sewage sludge-spruce wood mixture under inert atmosphere was performed using NETZSCH STA 449 F3 Jupiter thermal analyser with $\mathrm{SiC}$ furnace and TG sample carrier with S-type temperature sensor calibrated for $260 \mathrm{mg} \mathrm{Pt} / \mathrm{Rh}$ TG crucibles. The crucibles were covered with a pierced lid. The temperature program of the TG furnace was from $45^{\circ} \mathrm{C}$ to $900^{\circ} \mathrm{C}$ 
Table 1. Proximate and ultimate analysis of the tested materials

\begin{tabular}{cccc}
\hline Parameter & Sewage sludge & Spruce & Mixture 50:50 wt.\% \\
\hline Proximate analysis wt.\% & & & \\
\hline Moisture & 4.0 & 3.6 & 3.8 \\
\hline Volatiles & 51.1 & 79.2 & 65.1 \\
\hline Fixed carbon & 13.9 & 16.8 & 15.4 \\
\hline Ash & 31.0 & 0.4 & 15.7 \\
\hline HHV (MJ/kg) & 17.3 & 20.3 & 18.8 \\
\hline Ultimate analysis wt.\% (dry basis) & & & 44.93 \\
\hline Carbon & 40.05 & 49.80 & 5.83 \\
\hline Hydrogen & 5.15 & 6.50 & 29.80 \\
\hline Oxygen (diff. ${ }^{*}$ ) & 16.40 & 43.20 & 2.96 \\
\hline Nitrogen & 5.85 & 0.06 & 0.80 \\
\hline Sulphur & 1.55 & 0.04 & \\
\hline
\end{tabular}

* Determined by difference

at heating rates of $5,10,15$, and $20^{\circ} \mathrm{C} / \mathrm{min}$. Nitrogen gas flow of $60 \mathrm{ml} / \mathrm{min}$ was supplied into the TG furnace as an inert atmosphere for pyrolysis conditions. TG curves were recorded and the properties of DTG curves were calculated using Proteus v6.0.0 software.

\section{Evolved gas analysis by FT-IR}

In the present study, the analysis of gas evolved during thermal decomposition of the samples was performed by TG coupled Fourier-transform infrared (FTIR) spectrometer. FTIR analysis was performed on Bruker Tensor 27 with specially designed TGA-IR module. TG-FTIR coupling interface is a PTFE tube with the inner diameter of $1 \mathrm{~m}$ and $1.6 \mathrm{~mm}$, heated to $250^{\circ} \mathrm{C}$ for prevention of condensation of the evolved gases. The evolved gases are self-flowing through the heated interface into heated FTIR gas cell with $\mathrm{KBr}$ (internal) and $\mathrm{ZnSe}$ (external) windows and optical path length of $123 \mathrm{~mm}$. The gas cell is located inside the external TG-FTIR module of the spectrometer. The module is equipped with a mercury cadmium telluride (MCT) detector with an integrated preamplifier. The detector operates at liquid nitrogen temperature. The infrared source provides signal in the middle infrared range (MIR) of $4500-400 \mathrm{~cm}^{-1}$, but due to the characteristics of the MCT detector, IR absorbance spectra were recorded in the $4500-650 \mathrm{~cm}^{-1}$ wavenumber region. Scan resolution was $4 \mathrm{~cm}^{-1}$ and sample scan time 32 seconds. With these conditions, spectra were recorded continuously at the intervals of about 14 seconds for each of the experiments. FTIR data was processed and exported using Opus v6.5 software.

\section{Reaction kinetics}

For derivation of the pyrolysis kinetic data, four TG heating rates were used. The reaction rate of heterogeneous solids can be described by the main equation:

$$
\frac{d \alpha}{d t}=k(T) f(\alpha)
$$

where $a$ - conversion, $t$ - time, $k(T)$ - temperature dependent constant, and $f(\alpha)$ - differential function of conversion. It is convenient to transform the above expression into non-isothermal case describing reaction as a function of temperature by using constant heating rate:

$$
\beta=d T / d t=\text { const. }
$$

Conversion of (2) Arrhenius equation describes the temperature dependence of the conversion rate:

$$
\frac{d \alpha}{d \mathrm{~T}}=\frac{1}{\beta} A \times \exp \left(\frac{-E}{R T}\right)
$$

where $A$ - pre-exponential factor, $E$ - activation energy, $R$ - the universal gas constant.

In non-isothermal kinetics, a series of thermogravimetric experiments must be conducted 
at different heating rates. Analysis of the experimental data shows that conversion a depends on the temperature only for the same material and its mass loss. Then, reliable values of the constants $A$ and $E$ are found. This method of analysis was examined in detail by Flynn [18], Ozawa et al. [15]; universal approximation was found by Doyle [19], where function $p(E / R T)$ is valid within $7<E /$ $R T<60$ range. Having the constants of the Arrhenius law, it is possible to estimate the specifics of reaction progress from measurement data and find reaction order by the so-called double logarithm equation:

$$
[-\ln (1-\alpha(T))]=\ln A-\frac{E}{R T}-n \ln \beta .
$$

Reaction order is derived by plotting the rightside logarithm against $\ln \beta$ at $T=$ const for different $\beta$ values. Equation (5) is adapted from the approach suggested by Avrami [17] after the analysis was done for a non-isothermal case and for different $\beta$ values.

$$
\alpha(T)=1-\exp \left(\frac{-k(T)}{\beta^{n}}\right)
$$

By these theoretical formulas, experimental results were generalized by dividing pyrolysis reactions into three parts: pyrolysis of amorphous compounds within the temperature range up to $320^{\circ} \mathrm{C}$, cellulose dominant range up to $380^{\circ} \mathrm{C}$, and carbon bond containing molecules, such as lignin, up to $500^{\circ} \mathrm{C}$.

\section{RESULTS AND DISCUSSION}

\section{Thermal analysis}

Results of thermogravimetric analysis are shown in Fig. 1 for all three materials studied. After the dehydration of the sample, the main stage of decomposition takes place at the temperature of $250^{\circ} \mathrm{C}$. First, it is mandatory to get acquaintance with all three stages of the TG mass loss. In the case of spruce, the largest mass loss is linked with cellulose decomposition, which occurs at $320-390^{\circ} \mathrm{C}$. In the case of sewage sludge, the curve of TG mass loss is most intense at 250$330^{\circ} \mathrm{C}$ temperature zone, which is completely different from spruce. In the case of the mixture, mass loss is rather superposition of two sepa- rate materials and the process takes place up to $360^{\circ} \mathrm{C}$. DTG curves represent the dynamics of the main mass loss versus temperature. Constant trend of the sample mass loss is observed for spruce and for sewage sludge with maximum mass loss at the above-mentioned temperatures. The mixture case is special, since the shoulder in the progress of the DTG curve is the composition of the two constituent materials.

Results presented in Fig. 1 reveal differences in pyrolysis mass loss of different materials, namely, sewage sludge and spruce. If wood pyrolysis represents the sum of its constituents such as hemicellulose, cellulose, and lignin, in the case of sewage sludge main mass decomposition (60\% organics) occurs at the temperature of up to $350^{\circ} \mathrm{C}$. This means that in sewage sludge composition, a system of amorphous organic materials dominates that can be described as closely related to hemicellulose. Digested sewage sludge does not contain pure cellulose, but does contain many organic compounds with simple carbon bonds, such as yeast shells, nitrogen-containing organics, and so on, and the process of pyrolysis of this material goes faster than lignin.

In all cases of TG, we can judge that initial composition of the raw material contains three constituents. This allows pyrolysis process kinetics to be described as wood pyrolysis with separate zones of hemicellulose, cellulose, and lignin by selecting data points where we find all three Arrhenius $E, A, n$ triplet constants by least squares method with match of experimental TG curve. The results achieved are presented in Table 2, at heating rate $\beta=10^{\circ} \mathrm{C} / \mathrm{min}$. It is worth mentioning that acquired $E$ values were in between $+-5 \%$, a slight change of the $E$ value was used within this limit to approach the $n=1$ value.

In this work, the pyrolysis residue is defined at $500^{\circ} \mathrm{C}$. Starting from this temperature, mass loss is relatively negligible and tar-containing carbon residue dominates. Finally, mineral content and small carbon residue remain at higher temperatures. We performed pyrolysis of spruce pellets using a cylindrical bench-scale fixed-bed reactor with space $55 \mathrm{~mm}$ in diameter and twice as long [21]. The pyrolysis process ends at the temperature of $500^{\circ} \mathrm{C}$. The char to fuel weight ratio was found to be 0.247 and final carbon residue with minerals left was $0.14 \mathrm{wt} . \%$ at the $900^{\circ} \mathrm{C}$. 

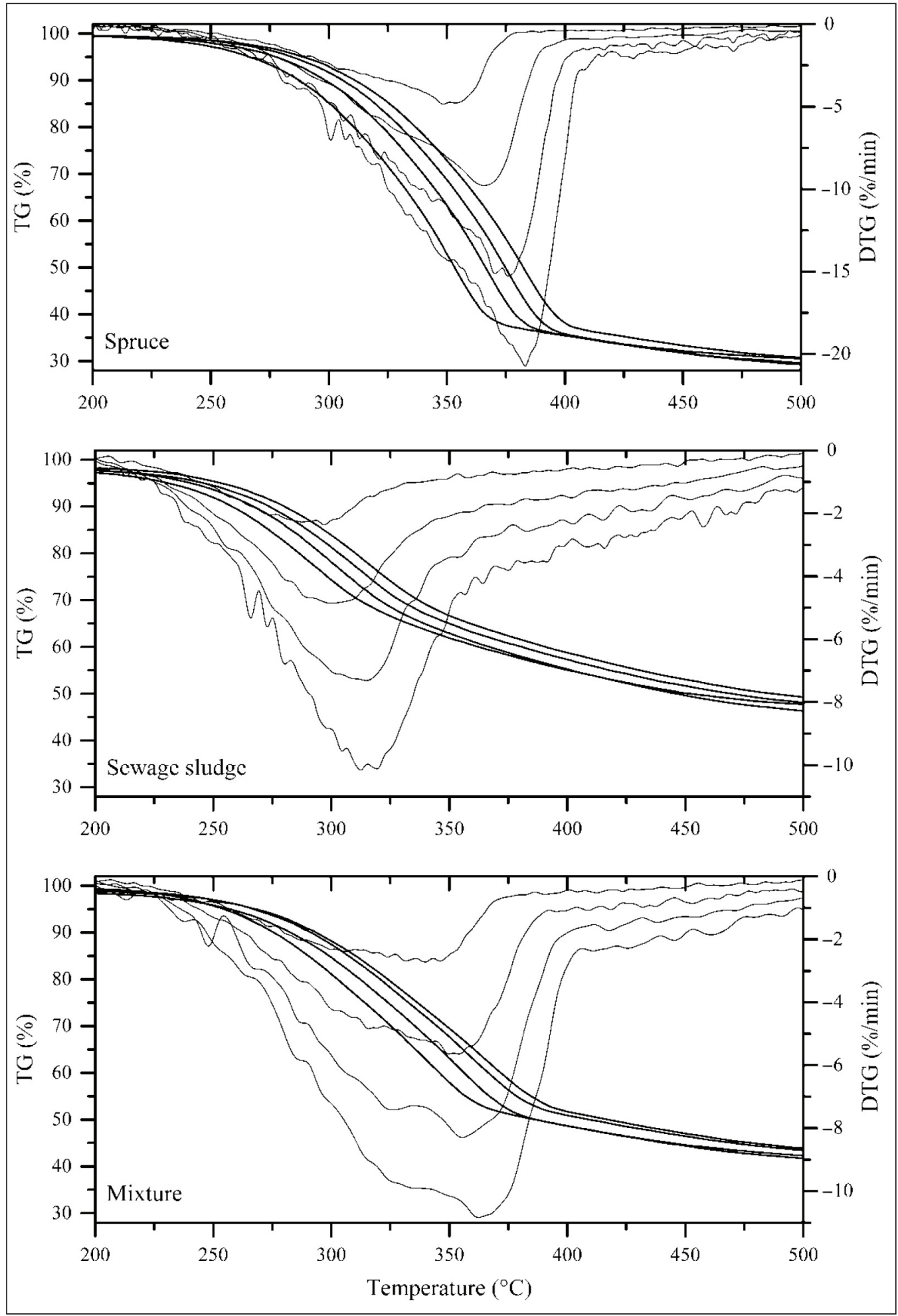

Fig. 1. TG mass loss (left axis, thicker lines) and DTG curves for the materials studied. The faster heating rate $\beta$, the more intense (DTG) and more inert with temperature (TG) the curves at $\beta=5,10,15$ and $20^{\circ} \mathrm{C} / \mathrm{min}$, respectively

Pyrolysis process can be modelled taking into consideration that each group of organic compounds from the total content has constant mass values in the initial stage, $m_{01}, m_{02}, m_{03}$. Pyrolysis of each group follows the Arrhenius law triplet according to the recorded TG curve, and the total 
Table 2. Kinetic parameters of the materials studied

\begin{tabular}{cccccccc}
\hline Activation energy $\mathbf{E}, \mathbf{k J} / \mathbf{m o l}$ & Pre-exponential factor A & Reaction order $\mathbf{n}$ & Initial mass fraction \\
\hline \multicolumn{7}{c}{ Spruce } \\
\hline$E_{1}$ & 155 & $A_{1}$ & $2.30 \cdot 10^{11}$ & $n_{1}$ & 1.0 & $m_{01}$ & 0.19 \\
\hline$E_{2}$ & 157 & $A_{2}$ & $4.20 \cdot 10^{12}$ & $n_{2}$ & 1.0 & $m_{02}$ & 0.31 \\
\hline$E_{3}$ & 54.7 & $A_{3}$ & $2.63 \cdot 10^{3}$ & $n_{3}$ & 1.1 & $m_{03}$ & 0.22 \\
\hline & & & & & residue & 0.28 \\
\hline$E_{1}$ & 153 & $A_{1}$ & $8.10 \cdot 10^{12}$ & $n_{1}$ & 1.0 & $m_{01}$ & 0.28 \\
\hline$E_{2}$ & 143 & $A_{2}$ & $1.22 \cdot 10^{11}$ & $n_{2}$ & 1.0 & $m_{02}$ & 0.18 \\
\hline$E_{3}$ & 80.4 & $A_{3}$ & $2.65 \cdot 10^{5}$ & $n_{3}$ & 1.0 & $m_{03}$ & 0.06 \\
\hline & & & & & residue & 0.48 \\
\hline$E_{1}$ & 172 & $A_{1}$ & $1.20 \cdot 10^{14}$ & $n_{1}$ & 1.0 & $m_{01}$ & 0.20 \\
\hline$E_{2}$ & 168 & $A_{2}$ & $7.65 \cdot 10^{12}$ & $n_{2}$ & 1.0 & $m_{02}$ & 0.25 \\
\hline$E_{3}$ & 56.5 & $A_{3}$ & $2.67 \cdot 10^{3}$ & $n_{3}$ & 1.0 & $m_{03}$ & 0.07 \\
\hline & & & & & & residue & 0.43 \\
\hline
\end{tabular}

reaction process is the sum of the three distinguishable parts of the reaction. Such model proved itself when reaction order $n$ approached the value of 1 and the modelled curve matched the experimental TG curve.

The triplet of the Arrhenius law constants was found by calculating activation energy $E$ and pre-exponential factor $A$ according to the standard approximation procedure [14] for each three of the constituent part groups. The DTG curves are used to distinguish the groups of materials, and constants $E$ and $A$ are applied by finding them from the TG data. By using non-isothermal isoconvertional method for all $\beta$, we can find reaction order $n$ by the equation (4).

\section{Evolved gas analysis}

The IR spectra during TG temperature ramp were recorded about every $14 \mathrm{~s}$ and produced $3 \mathrm{D}$ cube array data. Absorbance intensity of evolved gases, consequently Gram-Schmidt diagram, and the mean value of absorbance were most intense at $20^{\circ} \mathrm{C} / \mathrm{min}$ heating rate rather than lower heating rates and FTIR data analysis at this heating rate is presented in Figs. 2, 3, and 4. Compounds that were selected for identification were $\mathrm{CO}, \mathrm{CO}_{2}, \mathrm{CH}_{4}, \mathrm{NH}_{3}$, alkyl and carbonyl groups, and carbohydrates: acids and aldehydes $(\mathrm{C}=\mathrm{O})$, aromatic rings, and alkenes $(\mathrm{C}=\mathrm{C})$. The analysis data are shown in Fig. 2.

Analysis of all materials clearly shows that peak evolution of the gases corresponds to TG mass loss and DTG maximum. The GramSchmidt diagram (Fig. 2) shows integrated infrared absorption value of total evolved gases during TG experiment. The more intense GramSchmidt diagram of the spruce sample is related to a higher content of volatiles. $\mathrm{CO}_{2}$ evolution is indicated by absorbance spectra at wavenumber $2360 \mathrm{~cm}^{-1}$, and CO is represented by absorbance at $2183 \mathrm{~cm}^{-1}$. $\mathrm{CO}_{2}$ concentration is higher from sewage sludge than from spruce. Higher concentration of $\mathrm{CO}_{2}$ at lower temperatures from sewage sludge sample is caused by pyrolysis of low polymerized amorphous organic molecule structures. A higher concentration of $\mathrm{CO}$ is released from spruce, and it is related to cellulose specific pyrolysis. The evolution profile of $\mathrm{CH}_{4}$ is similar for all the materials, however, in the case of the mixture, we can observe two shoulders of the absorption profile with minimum at about $400^{\circ} \mathrm{C}$, which is not recognized as an average, or superposition, of the two primary materials.

TG-FTIR measurements of gases are based on absorption of infrared radiation, and the absorption intensity depends on the bond type of the molecules. In order to evaluate the relative 


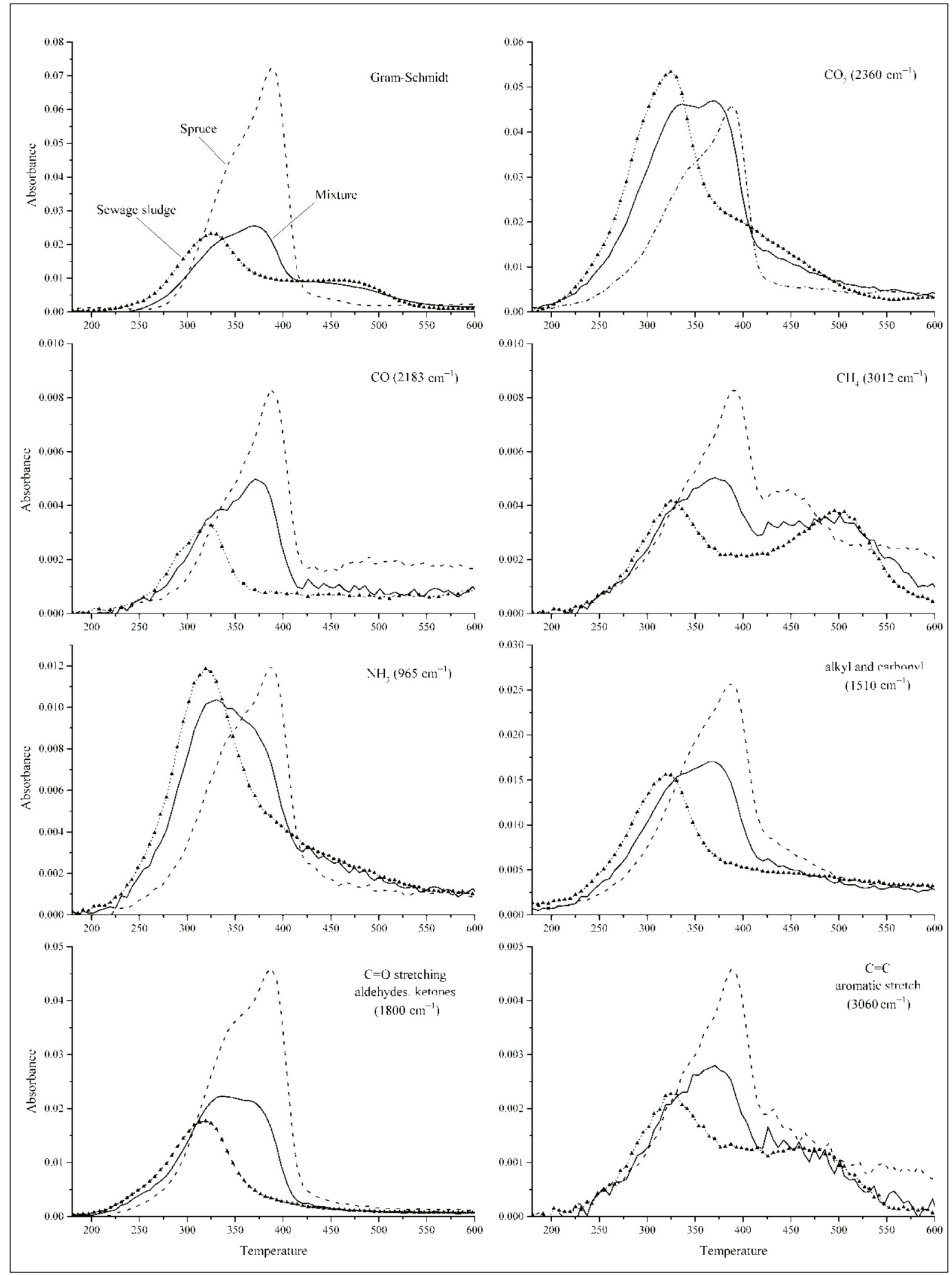

Fig. 2. FTIR absorption profiles of evolved gases for different materials as function of temperature at heating rate $20^{\circ} \mathrm{C} / \mathrm{min}$ (spruce - -, mixture --, sewage sludge - $\mathbf{\Delta}$-) 
quantity of the evolved species during TG-FTIR measurements, absorption intensity values at constant wavelengths, representing molecules such as $\mathrm{CO}$ or $\mathrm{CO}_{2}$ were compared for all three materials. These values, obtained at the most intense mass loss temperature, are presented in Table 3.

For comparison, instrumental measurements of the evolved gases during pyrolysis of spruce pellets, results for $\mathrm{CO}, \mathrm{CO}_{2}, \mathrm{CH}_{4}$ from the bench-scale reactor [21] are presented in Table 4. Pyrolysis of spruce pellets in the benchscale reactor was performed at temperatures of 340 and $500^{\circ} \mathrm{C}$. Here, the permanent gas volume is presented excluding hydrocarbon volatiles, and these results agree with the reference work [3], p. 155, Figs. 5 and 6.

Table 3. Proportion of permanent gas quantity release for different materials

\begin{tabular}{c|c|c|c}
\hline Sample & $\mathbf{C O}$ & $\mathbf{C O}_{2}$ & $\mathbf{C H}_{4}$ \\
\hline Spruce & 1 & 1 & 1 \\
\hline Sewage sludge & 0.37 & 1.2 & 0.69 \\
\hline Mixture & 0.55 & 1.04 & 0.58 \\
\hline
\end{tabular}

Table 4. Permanent gas release for the pyrolysis of spruce pellets at a bench reactor. Measurement values in volume proportion

\begin{tabular}{c|c|c|c}
\hline Reactor temperature & $\mathbf{C O}$ & $\mathbf{C O}_{2}$ & $\mathbf{C H}_{4}$ \\
\hline $340^{\circ} \mathrm{C}$ & 0.37 & 0.26 & 0.03 \\
\hline $500^{\circ} \mathrm{C}$ & 0.36 & 0.24 & 0.06 \\
\hline
\end{tabular}

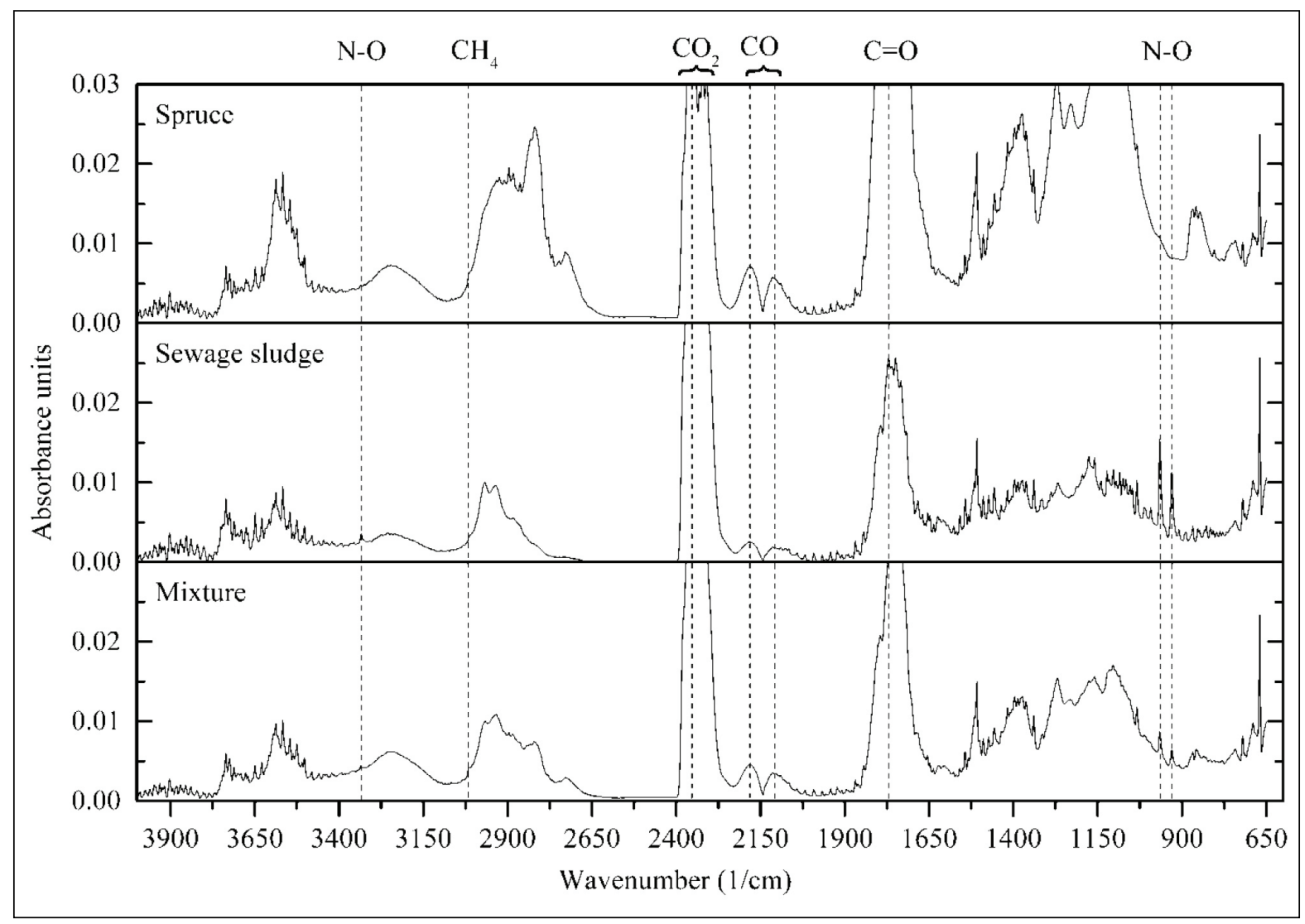

Fig. 3. FTIR absorption spectra of products evolved during pyrolysis at maximum mass loss temperatures: spruce $319^{\circ} \mathrm{C}$, sewage sludge $387^{\circ} \mathrm{C}$, mixture $371^{\circ} \mathrm{C}$ 
Absorption band at $1800 \mathrm{~cm}^{-1}$ infrared region is characteristic of the carbonyl group containing compounds, aldehydes, ketones, and esters, and is almost twice as intense in spruce sample as in sewage sludge. Aromatic compounds in the evolved gases are represented by 3060 and $1510 \mathrm{~cm}^{-1}$ absorption bands caused by $\mathrm{C}=\mathrm{H}$ and $\mathrm{C}=\mathrm{C}$ stretching, respectively. Light organic gas species (esters, carboxyl and carbonyl compounds, aliphatic hydrocarbons) evolves at a relatively narrow temperature range $\left(200-370^{\circ} \mathrm{C}\right)$ of decomposition $[22,23]$. At higher temperatures, above $400^{\circ} \mathrm{C}$, when carbon residue pyrolysis dominates, $\mathrm{C}=\mathrm{C}$ absorption profile at $3060 \mathrm{~cm}^{-1}$ proofs formation of aromatic compounds in the gases.

FTIR absorption spectra abundance of products evolved during pyrolysis at TG maximum mass loss temperatures of each material is presented in Fig. 2. The results presented in this figure are obtained by transporting evolved gases from TG furnace to FTIR detector by 1-metre-long PTFE tube heated at constant temperature of $250^{\circ} \mathrm{C}$. Distinguishable bands from sewage sludge sample from the others are at 3334,965 , and $930 \mathrm{~cm}^{-1}$. The $3334 \mathrm{~cm}^{-1}$ band is assigned to $\mathrm{O}-\mathrm{H}$ stretch vibrations which is relative to propylene oxide, and possibly to li- pides. This absorption band may also belong to $-\mathrm{NH}_{2}=\mathrm{NH}$ vibrations. The $965 \mathrm{~cm}^{-1}$ absorption peak belongs to the $\mathrm{C}$ - $\mathrm{CO}$ vibrations absorption zone of $1000-940 \mathrm{~cm}^{-1}$ relative to alkyl aryl ketones. The $950 \mathrm{~cm}^{-1}$ absorption peak is related to alkoxy groups. These three peaks were not found in the spruce sample, but the mixture indicates these effects. All these three distinct peaks at 930,965 , and $3334 \mathrm{~cm}^{-1}$ from the sewage sludge sample are also attributed to deformation and stretching vibrations of $\mathrm{N}-\mathrm{H}$ bond, and $\mathrm{NH}_{3}$ is related to it. The presence of these peaks was also confirmed by [24] using similar analytical technique on analysis of nitrogen-containing compounds and is a confirmation of nitrogen transformation reactions of the material with higher nitrogen content (Table 1).

Comparison of the gases evolved from all three samples was performed by calculating integral areas of specific wavelengths with respect to temperature at specific maximum mass loss of each material. The results are presented in Fig. 4. Spruce contains more polymeric material with a higher content of hydrocarbons and cellulose. Thus, pyrolysis of spruce produces more $\mathrm{CO}$ than sewage sludge and it is presented by comparing $\mathrm{CO}_{2}$ and $\mathrm{CO}$ trends in Fig. 4. The figure represents the quantity of evolved gases according to

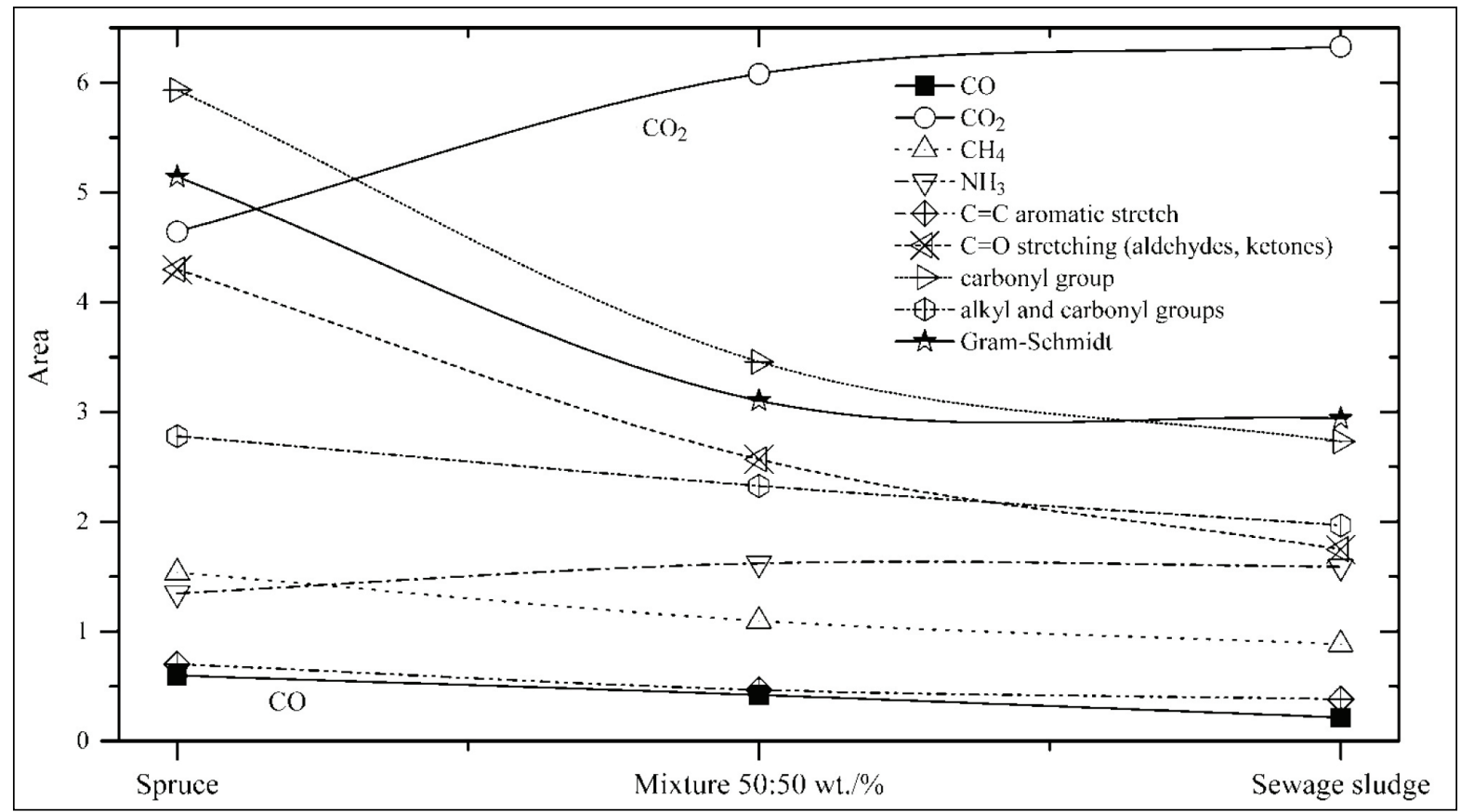

Fig. 4. Comparison of the FTIR measured evolved gas quantity for different materials 
the volatile content of the initial material. Sewage sludge is a material of amorphous structure and $\mathrm{CO}_{2}$ production is initiated by oxygen activity. The Gram-Schmidt diagram represents the average of all three samples. The ammonia quantity rises towards the increase of sewage sludge quantity.

\section{CONCLUSIONS}

Nowadays municipal sewage sludge is treated by anaerobic digestion and storage for later gasification or burning. Detailed experimental investigations of the process of pyrolysis of the Norway spruce, digested sewage sludge, and a 50:50 mixture of both materials was performed using TG technique. By the example of the components of wood, the raw material was explored as three parts containing TG data; in the case of sewage sludge, it was obvious that it was the basis for such an assessment (Table 2). Analysis of mixture material revealed pyrolysis process as superposition of two original materials. All the measurement data were generalised as a triplet of the constants $-A, E$, and $n-$ of the Arrhenius law. At the most intense mass loss of the materials, the Arrhenius constants were $E=150 \mathrm{~kJ} / \mathrm{mol}$ at $320-380^{\circ} \mathrm{C}$ for spruce, $E=150$ at $270-330^{\circ} \mathrm{C}$ for sewage sludge, and $E=150$ at $270-370^{\circ} \mathrm{C}$ for the mixture. In the case of the mixture, the DTG curve shows shoulders of the pyrolysis process. In almost all cases, reaction order approximates the value of 1 (Table 2). Residual masses of sewage sludge due to inorganic materials were always higher.

A good correlation between the highest mass loss rate according DTG and abundance of evolved gases in TG-FTIR mode was found. The most intense gas production was for spruce at $360^{\circ} \mathrm{C}$, for sewage sludge at $325^{\circ} \mathrm{C}$, and for the mixture at $375^{\circ} \mathrm{C}$. This rule is obvious for all the gases, except $\mathrm{CH}_{4}$, where two peaks at temperatures 325 and $500^{\circ} \mathrm{C}$ are seen for sewage sludge. This results in the shoulders of the temperature profile curve of the mixture sample. TG-FTIR measurements are based on the capability of infrared light absorption of gases and relative emission quantity, as well as on comparisons of specific gases, $\mathrm{CO}, \mathrm{CO}_{2}$, and $\mathrm{CH}_{4}$. The case of spruce, with the results of bench-scale reactor test, is presented in this article.

Received 15 April 2021 Accepted 10 August 2021

\section{References}

1. Urban D. L., Antal Jr. M. J. Study of the kinetics of sewage sludge pyrolysis using DSC and TGA. Fuel. 1982. Vol. 61. No. 9. P. 799-806. doi: 10.1016/0016-2361(82)90306-4.

2. Igarashi M., Hayafune Y., Sugamiya R., Nakagava Y., Makishima K. Pyrolysis of municipal solid waste in Japan. Journal of Energy Resources Technology. 1984. Vol. 106. No. 3. P. 377-382. doi: 10.1115/1.3231068.

3. Basu P. Biomass gasification, pyrolysis and torrefaction. 2013, Academic Press, Elsevier. ISBN: 978-012-396488-5. $548 \mathrm{p}$.

4. Branca C., Di Blasi C., Galgano A., Brostrom M. Effects of the torrefaction conditions on the fixedbed pyrolysis of Norway spruce. Energy Fuels. 2014. Vol. 28. No. 9. P. 5882-5891. doi: 10.1021/ ef501395b.

5. Greenhalf C. E., Nowakowski D. J., Bridgwater A. V., Titiloye J., Yates N., Riche A., Shield I. Thermochemical characterisation of straws and high yielding perennial grasses. Industrial Crops and Products. 2012. Vol. 36. No. 1. P. 449-459. doi: 10.1016/j.indcrop.2011.10.025.

6. Yang H., Yan R., Chen H., Lee D. H., Zheng Ch. Characteristics of hemicellulose, cellulose and lignin pyrolysis. Fuel. 2007. Vol. 86. No. 12-13. P. 1781-1788. doi: 10.1016/j.fuel.2006.12.013.

7. Conesa J. A., Marcilla A., Prats D. Kinetic study of the pyrolysis of sewage sludge. Waste Management and Research. 1997. Vol. 15. No. 3. P. 293-305. doi: 10.1006/wmre.1996.0085.

8. Yang J., Chen H., Zhao W., Zhou J. Combustion kinetics and emission characteristics of peat by using TG-FTIR technique. Journal of Thermal Analysis and Calorimetry. 2016. Vol. 124. P. 519528. doi: 10.1007/s10973-015-5168-x.

9. Striūgas N., Zakarauskas K., Džiugys A., Navakas R., Paulauskas R. An evaluation of performance of automatically operated multi-fuel downdraft gasifier for energy production. Applied Thermal 
Engineering. 2014. Vol. 73. No. 1. P. 1151-1159. doi: 10.1016/j.applthermaleng.2014.09.007.

10. Calvo L. F., Otero M., Jenkins B. M., Garcia A. I., Moran A. Heating process characteristics and kinetics of sewage sludge in different atmospheres. Thermochimica Acta. 2004. Vol. 409. No. 2. P. 127135. doi: 10.1016/S0040-6031(03)00359-9.

11. Lin Y., Liao Y., Yu Zh., Yu Zh., Fang Sh., Lin Yo., Fan Y., Peng X., Ma X. Co-pyrolysis kinetics of sewage sludge and oil shale thermal decomposition using TGA-FTIR analysis. Energy Conversation Management. 2016. Vol. 118. P. 345-352. doi: 10.1016/j.enconman.2016.04.004.

12. Magdziarz A., Wilk M. Thermogravimetric study of biomass, sewage sludge and coal combustion. Energy Conversation Management. 2013. Vol. 75. P. 425-430. doi: 10.1016/j.enconman.2013.06.016.

13. Otero M., Gómez X., Garcia A. I., Moran A. Non-isothermal thermogravimetric analysis of the combustion of two different carbonaceous materials. Journal of Thermal Analysis and Calorimetry. 2008. Vol. 93. P. 619-626. doi: 10.1007/ s10973-007-8415-y.

14. ASTM E1641-16, Standard test method for decomposition kinetics by thermogravimetry using the Ozawa/Flynn/Wall method, ASTM International, West Conshohocken, PA, 2016, www.astm. org. doi: 10.1520/E1641-16.

15. Ozava T. Kinetics of non-isothermal crystallization. Polymer. 1971. Vol. 12. P. 150-158. doi: 10.1016/0032-3861(71)90041-3.

16. Lambrigger $M$. Non-isothermal crystallization kinetics of poly(ethylene terephthalate) from the point of view isokinetic models. Polymer Journal. 1998. Vol. 30. P. 262-264. doi: 10.1295/ polymj.30.262.

17. Avrami M. Granulation, phase change, and microstructure kinetics of phase change. III. The Journal of Chemical Physics. 1941. Vol. 9. No. 2. P. 177183. doi: 10.1063/1.1750872.

18. Flynn J. H., Wall L. A. A quick, direct method for the determination of activation energy from thermogravimetric data. Journal of Polymer Science, Part B: Polymer Letters. 1966. Vol. 4. P. 323-328. doi: 10.1002/pol.1966.110040504.

19. Doyle C. D. Kinetic analysis of thermogravimetric data. Journal of Applied Polymer Science. 1961. Vol. 5. No. 15. P. 285-292. doi: 10.1002/ app.1961.070051506.

20. Gao N., Li J., Qi B., Li A., Duan Y., Wang Z. Thermal analysis and products distribution of dried sewage sludge pyrolysis. Journal of Analytical and Applied Pyrolysis. 2014. Vol. 105. P. 43-48. doi: 10.1016/j.jaap.2013.10.002.

21. Šlančiauskas A. Heat transfer measurements in wood feedstock for two-staged gasifier case. Advances in heat transfer, Proceedings of the Baltic Heat Transfer Conference 2015, Tallinn. P. 285290. ISBN 978-9949-23-817-0.

22. Yang J., Chen H., Zhao W., Zhou J. TG-FTIR-MS study of products evolving from peat. Journal of Analytical and Applied Pyrolysis. 2016. Vol. 117. P. 296-309. doi: 10.1016/j.jaap.2015.11.002.

23. Salema A. A., Afzal M. T., Motasemi F. Is there synergy between carbonaceous material and biomass during conventional pyrolysis? A TG-FTIR approach. Journal of Analytical and Applied Pyrolysis. 2014. Vol. 105. P. 217-226. doi: 10.1016/j. jaap.2013.11.007.

24. Quang D. V., Hatton T. A., Abu-Zahr M. R. M. Thermally stable amine-grafted adsorbent prepared by impregnating 3-aminopropyltriethoxysilane on mesoporous silica for $\mathrm{CO}_{2}$ capture. Industrial \& Engineering of Chemical Recourses. 2016. Vol. 55. P. 7842-7852. doi: 10.1021/acs.iecr.5b04096. 
Giedrius Straviskas, Anupras Šlančiauskas

MIESTO NUOTEKŲ DŽIOVINTO DUMBLO

IR MEDIENOS GRANULIŲ MIŠINIO

TERMOGRAVIMETRINE் PIROLIZE்

IR SUSIDARANČIŲ DUJŲ SUDE்TIES

NUSTATYMAS INFRARAUDONŲJŲ

SPINDULIŲ SPEKTROSKOPIJA

\section{Santrauka}

Miestų nuotekų džiovintas dumblas yra kaloringas ir tinkamas gaminti šilumą, o sumaišius su medienos granulemis tampa ekologiškesnis, todèl galima naudoti mažesniuose, toli nuo atliekas deginančių jègainių issikūrusiuose miestuose. Ši nuostata paskatino nuotekų džiovinto dumblo ir medienos granulių mišinio termogravimetrinę pirolizę (TG) ir susidarančių dujų sudèties tyrimus infraraudonųjų spindulių spektroskopija (FTIR). Daugiausia dumblo masès išsiskiria esant 300-310 ${ }^{\circ} \mathrm{C}$ temperatūrai, o medienos granulių, kuriose daug celiuliozès, maksimumas pasiekiamas ties $360^{\circ} \mathrm{C}$. Pagrindiniai tyrimai atliekami su šių medžiagų mišiniu (50 : 5000 \%). Remiantis TG duomenimis, surasta pirolizès reakcijų Arenijaus dèsnio pastovioji $A$ ir aktyvacijos energija $E$, o reakcijos laipsnio rodiklis $n$ nustatytas pagal Ozawos metodą, pasinaudojus fazès pokyčiais pagal Avrami. Dujų išskyrimo maksimumas visada siejasi su medžiagos netekties kiekiu, o išsiskyrusių dujų sudètis koreliuoja su pradine medžiaga.

Raktažodžiai: pirolizè, džiovintas miesto dumblas, dujų išeiga, spektroskopijos tyrimas 